the Atlantic, the general character of the weather of any coming season may be foretold.

The following statement has been issued from the Meteorological Office, London :--

"The Meteorological Council propose to undertake the preparation of daily weather charts of the North Atlantic Ocean for the thirteen months beginning on August I in he present year, and ending on August 31, 1883 .

"It is well known that the changes of weather which we experience are in general caused by atmospheric disturbances, which travel more or less rapidly, and undergo more or less modification during their progress. By far the larger number of the disturbances which visit the British Islands arrive on our shores from the Atlantic Ocean, and our earliest information as to any impending change is consequently derived from telegraphic reports from the Atlantic coasts, especially from the British stations at Stornoway, Mullaghmore, and Valentia, and occasionally from the Continental observatories at Rochfort and Corunna. But of the origin and previous history of these systems we have no sufficient knowledge, except in a few isolated cases.

"The Meteorological Council believe that any systematic information which can be obtained as to the origin development, and laws of motion of the atmospheric disturbances which occur over the Atlantic Ocean would promote the science of meteorology and be of immediate benefit to seamen traversing the Atlantic Ocean, and would tend directly to the improvement of the forecasts and storm warnings issued to the British coasts, ky rendering the interpretation of the first indications of approaching changes observed at the western meteorological stations more easy and certain.

"The importance of a systematic study of the weather of the North Atlantic Ocean has long been recognised, and series of daily synoptic charts, more or less resembling those now in contemplation, have been prepared at various times, not only by the Meteorological Office, but also by the Association Scientifique de France under the guidance of Leverrier, by Capt. Hoffmeyer, of the Danish Meteorological Institute, by the Deutsche Seewarte, at Hamburg, and (as a part of a wider plan) by the Chief Signal Office of the United States. But none of these charts, however valuable in other respects, supply adequate materials for a satisfactory discussion of Atlantic weather, chiefly on account of the small number of the observations upon which they are founded as compared with the magnitude of the area over which they are spread.

"Evidence of the interest attaching to the connection between English and Atlantic weather is afforded by the efforts which have been made during the last few years by the proprietors of the New York Herald to transmit to England from America telegraphic predictions of approaching disturbances, which (it is presumed) are founded on the reports of vessels arriving in America from the Atlantic Ocean. Reports such as these from a large number of vessels would be of great value; but the predictions taken by themselves cannot be utilised in a scientific investigation of weather.

"The Meteorological Council gratefully acknowledge the large measure of invaluable help which they have hitherto received from seamen and the shipping interest generally. But as the olject now proposed can only be achieved by the voluntary cooperation of an increased number of ob. servers, they feel justified in making a special appeal for assistance to the owners, captains, and officers of ships, and especially to the great companies whose steamers ply between this country and America. In a science which, like meteorology, is still in its infancy, every advance is attended with great difficulties, and the Council are well aware that it would be easy to be too sanguine as to the importance of the results to be obtained by the inquiry which they are about to undertake. But having regard to the loss of life and property occasioned by storms orr our coasts, ${ }^{1}$ they feel confident that their proposal will commend itself to the public gentrally, and will insure the active co-operation of those classes of the community for whose benefit it is primarily intended.

"It is proposed to ask for observations of the barometer, of open air and sea-surface temperatures, wind (direction and force) and weather at 8 a.m. and noon each day, with the position of the ship at noon.

"Forms for recording the observations will be supplied by the Meteorological Office, I16, Victoria Street, London, S.W., on application to the Marine Superintendent."

\section{PISCICULTURE IN THE EDINBURGH FISHERY EXHIBITION}

$\mathrm{I}$ was a happy thought of the promoters of the Fishery

Exhibition to secure the Aquarium for the use of their visitors. Although it is on a small scale, it adds largely to the amenities of the exposition, and must prove a novel sight to many inland visiturs. At most of the French fishery exhibitions, and at Arcachon in particular, an aquarium proved one of the greatest of the many attractions provided for the thousands who came to the châlet which contained the general exhibits. It must be confessed, however, that the French made more use of their aquarium than the directors of the Edinburgh Exhibition seem inclined to do-we miss some of the wonders of the deep in the shape of "fancy fishes," which we think might have been included in the present "show." There is one exhibit, however, which helps to make up for numerous deficiencies; we allude to entry No. 23 in the Catalogue, which is as follows:-

Musynski, Constantine, St, Petersburg.

Io, 000 live fry of the species Coregonus Bacri (Sigue), sent from St. Petersturg to this Exhibition (see in Aquarium).

There is much more in this simple entry than all at once meets the mind's eye. The fact of these young fish being in Edinburgh signifies a piscicultural feat of great importance. That impregnated fish eggs can be, and have been forwarded to great distances we know, but, as regards young fish, it has hitherto been a pretty general opinion that it would not be safe to send them a journey that would occupy a longer period than from twenty to thirty hours. Now we are disiliusioned as to that : in the Waverley Hall, at Edinburgh, we see ten thousand young fish in a healthy and lively state, that have come from a place which is two thousand miles distant. The problem of supplying these young fish with air during their long journey was solved in a very simple way, a glass tube of small diameter being inserted in the cork, whilst the shape of the great bottle (a carboy?) in which the fish travelled, insured the constant motion of the water. At all events, in whatever way this feat was accomplished, the young fish arrived in safety, the percentage of deaths being of no consequence-not 3 per cent., we believe. In connection with this Russian gift, a vexed question bas arisen at the Exhibition. Put in simple form, it is, Now that we have got these fish, what use can we make of them? It is quite clear that we cannot return them to Russia, and whether it would be safe to add them to the stock of any of our lochs has given rise to much controversy. It was first of all proposed to place them in Loch${ }^{2}$ The wreck return published by the Board of Trade for the year ending Jure 30,1880 (C. 2 co6) (the last published), gives on $\mathrm{p}$. 20 the following list
of casualties on cur coasts attributakle to causes connected with the

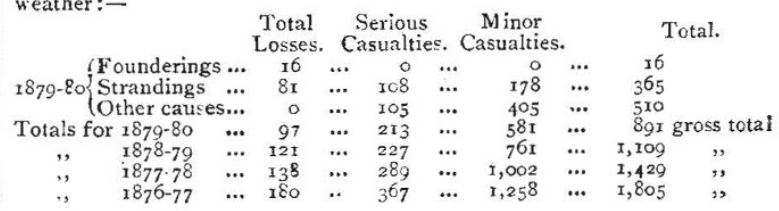


leven, but, at such a prospect, anglers have taken alarm, fearful lest the newcomers, when they have attained their full size, may devour the "finest trout in the world"Salmo levensis-a fish which has been compared with the Fario lemanus of the Lake of Geneva ; and in consequence of this opposition of the anglers, the Coregoni will probably find a home in Duddingston Loch, near Edinburgh, which, however, is much too small for such a large number of fish. Why not place the Russians in some of the lakes of Scotland, which already contain similar fish, in the town loch of Lochmaben, for instance, the home of the Vendace, or in Lochlomond, where may be seen the Powan? Or some hundreds of them might be sent to Loch Neagh in Ireland, whish contains the Pollan. Hoping that a suitable home may be found for these finny treasures, it will be interesting to note their future growth, to ascertain when they breed, how long it is till the spawn comes to life, and at what age the fish become reproductive.

The Edinburgh Exhibition is undoubtedly indebted to Sir James Gibson Maitland for a good show of young fish ; "live Salmonidæ artificially reared," at his extensive fishery of Howietoun near Stirling, where there is accommodation for the hatching of many millions of fish eggs. Sir James has directed his attention chiefly to the breeding of the trout of Lochleven, in which he has been exceedingly successful, also salmon, and the common trout of the country, as well as the Sulmo Fontanalis of America. Howietoun is a commercial fishery, from which supplies of fertilised eggs and "eyed ova" of the fishes named may be procured at a given price. The proprietor has an exhibit in the Waverley Hall (No. I68 in Catalogue) of hatching and other apparatus incidental to the piscicultural operations carried on at his fishery. It has been found in the course of the routine work at Howietous, that it is possible to transport eyed-ova with perfect safety to any part of the United Kingdom, and apparatus are shown suitable for the transport of large trout, providing for the automatic aëration of the water by means of a wedge of perforated zinc in the lid; there is also shown a "packing-case for transport of ova for long distances, with air chamber, ice tray, and ventilation of ova." It may interest persons interested in Pisciculture to know that the chief food supplied to the young fisbes at Howietown is horseflesh, three or four horses being used every week; the Lochleven trout are fed on clams procured from the Firth of Forth, and Sir James Maitland, we believe, is also growing snails for the purpose of feeding the young fish.

It may, we think, be taken for granted that the piscatorial feat which we have recorded, the transport of the fry from St. Petersburg to Edinburgh will give such a decided fillip to piscatorial operations of all kinds as may prove beneficial ; there are many barren sheets of water which might be advantageously populated with some one or other of the many species of the finny tribe, whilst proprietors of lakes or rivers which are tending to barrenness cannot do better than restock them with fry of the far-famed Lochleven trout, or of the $S$. fontanalis of America, the latter for running streams, the former for sheets of water of some magnitude.

THE EDINBURGH CHAIR OF NATURAL HISTOR $Y$

PROF. RAY LANKESTER, who has resigned the Edinburgh Chair of Natural History, which he accepted a fortnight ago, has requested us to publish the following statement :-

I have elsewhere stated the reasons which have led me, with very great regret and after anxious consideration, to withdraw from the honourable position of Regius Professor in the Edinburgh University, before actually entering upon the duties of the office. They, briefly stated, amount to this-that I had formed a mistaken estimate as to the extent to which the Professor's time would be occupied, the appliances at his disposal, and the security of his emoluments. For this mistake I am anxious to state that I accept the painful responsibility. At the same time I desire to say to those to whose support and interest in the matter I have been and remain so deeply indebted, that the warmth of the contest, which has occasioned no small expenditure of time and trouble to them--expenditure which I must ever remember with gratitude, and unfortunately also with deep regretexplains and, I hope, may be considered as excusing the tardiness of my arrival at a correct estimate of the desirability of exchanging my position in London for that in Edinburgb.

I have also to explain that it was solely a desire to give the least inconvenience possible to the authorities, which led me to communicate my resignation, and the reasons for it, to those whom it affected, without any delay. It has been pointed out to me, that my action may have appeared abrupt, and wanting in consideration for otbers. I should wish, on the other hand, to say that the reflection that my resignation must cause considerable disappointment, and even annoyance, to those whom I had most reason to spare such feeling, led me to hesitate in taking action, until the necessity for making arrangements both in Edinburgh and in London, was so pressing, as to make the immediate statement of my intentions, to all persons concerned, imperative.

Lastly, I should wish to state that I should find my regret for the present occurrence greatly increased, were it supposed that I do not recognise the dignity and importance of the University of Edinburgh, and the high position of its professors. I can only say, that I am sincerely sorry that circumstances should render it, in my opinion, desirable to forego the honour of entering upon that association with the University which was contemplated, and of working with colleagues for whom I, in common with all men of science, have the greatest respect and esteem, and amongst whom I am proud to reckon personal friends. $\quad$ E. RAY LANKESTER

ON THE RELATIVE RESISTANCES OF LAND AND WATER TO WIND CURRENTS

I 1878 I received a grant from the Government Research Fund for the purpose of ascertaining the law of variation of wind velocities at different heights : and I found that the curves traced out by the velocities in relation to the heights were most nearly represented by the formula $V=v \sqrt{\frac{H+7^{2}}{h+7^{2}}}$, where $H$ and $h$ represent respectively the heights in feet of the high and low level stations above the ground, and $V$ and $v$ the respective velocities at those levels.

I have since then been making observations with the view of ascertaining the relative resistance of land and water to the aërial currents. These observations are very far from being complete, but I give the following results in the meantime, as they may be interesting.

$$
\begin{aligned}
& 6^{\prime \prime} \text { waves } \ldots \text { Sand. } 12.8: 13 \cdot 8 \text { miles per hour }=\mathbf{I}: \mathbf{I} \cdot 08 \\
& \begin{array}{lllll}
6^{\prime \prime} \text { waves } \ldots & 12.8: 13.8 \text { miles per hour }=1: 108 \\
6^{\prime \prime},, & \ldots & 13.65: 14.375,,,, \quad=1: 1.06
\end{array}
\end{aligned}
$$

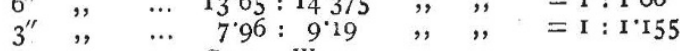

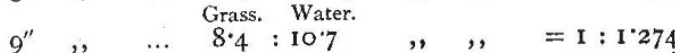

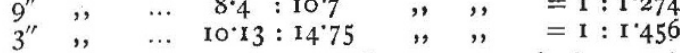

The velocities given are the means of observations taken every five minutes for about an hour.

From this it will be seen that the resistance is least for water, somewhat greater for smooth sand, and greater still for grass. Further observations are not only required on this subject, but also on the velocity of the wind over the water in relation to the height of the waves.

Edinburgh, April is
Thomas Stevenson 